Tabel 1: Struktur dan Tarif Pendapatan Asli Daerah

\begin{tabular}{lll}
\hline Pos & $\begin{array}{l}\text { Tarif } \\
\text { maksimal }\end{array}$ & $\begin{array}{l}\text { Pembagian } \\
\text { minimal ke desa }\end{array}$ \\
\hline Pendapatan asli daerah & & \\
\hline Pajak daerah & $10 \%$ & $10 \%$ \\
\hline Pajak hotel & $10 \%$ & $10 \%$ \\
\hline Pajak restoran & $35 \%$ & $10 \%$ \\
\hline Pajak hiburan & $23 \%$ & $10 \%$ \\
\hline Pajak reklame & $10 \%$ & $10 \%$ \\
\hline Pajak penerangan jalan & $20 \%$ & $10 \%$ \\
\hline Pajak pengambilan \& pengolahan bahan galian C & $20 \%$ & $10 \%$ \\
\hline Pajak parkir & & \\
\hline Retribusi daerah & Perda \\
\hline Jasa umum & Perda & \\
\hline Jasa usaha & Perda & \\
\hline Jasa tertentu & & \\
\hline Hasil pengelolaan kekayaan daerah yang dipisahkan & \\
\hline Lain-lain PAD yang sah & \\
\hline Hasil penjualan kekayaan daerah yang tidak dipisahkan; & \\
\hline Jasa giro; & \\
\hline $\begin{array}{l}\text { Pendapatan bunga; } \\
\text { Keuntungan selisih nilai tukar rupiah terhadap mata uang asing; } \\
\text { dan }\end{array}$ & \\
\hline $\begin{array}{l}\text { Komisi, potongan, ataupun bentuk lain sebagai akibat dari penjualan } \\
\text { dan/atau pengadaan barang dan/atau jasa oleh daerah. }\end{array}$ & \\
\hline $\begin{array}{l}\text { Sumber: UU } 34 / 2000 \\
\end{array}$ & \\
\hline
\end{tabular}

Sumber: UU 34/2000

Pemahaman yang menyatakan bahwa besarnya PAD merupakan indikator penting untuk menunjukkan keberhasilan Pemda (terutama Kabupaten) merupakan pemahaman yang keliru. Pemahaman ini yang seringkali memicu Pemda untuk melakukan pungutan-pungutan yang menghambat aktivitas ekonomi, atau membuat Pemda terlalu konsentrasi mengurusi usahanya sendiri (lewat perusahaan daerah) daripada memberikan pelayanan dasar pada masyarakat.

Dibandingkan UU 25/1999, UU 33/2004 menyebutkan secara lebih jelas tentang komponen "Lain-lain PAD yang sah", yaitu:

1) Hasil penjualan kekayaan daerah yang tidak dipisahkan

2) Jasa giro

3) Pendapatan bunga

4) Keuntungan selisih nilai tukar rupiah terhadap mata uang asing

5) Komisi, potongan, ataupun bentuk lain sebagai akibat dari penjualan dan/atau pengadaan barang dan/atau jasa oleh daerah.

Di sini dapat dilihat ada hal yang menarik pada pos yang terakhir. Selama ini danadana yang bersifat komisi atau potongan dalam kegiatan pengadaan barang dan jasa (procurement) tidak memiliki pos anggaran khusus, sehingga memicu terjadinya tindakan korupsi, kolusi dan nepotisme (KKN). Hal ini dapat dipandang sebagai salah satu usaha untuk menutupi kebocoran uang negara.

\subsection{Dana Perimbangan}

Bagi daerah-daerah yang bergantung pada sumberdaya alam, dana perimbangan memegang bagian terbesar dalam pendapatan daerah. Hampir seluruh proyek-proyek pembangunan tergantung pada dana perimbangan. Sayangnya, dana perimbangan selalu tidak keluar secara lancar. Walaupun tahun anggaran dimulai pada setiap tanggal 1 Januari, dana perimbangan biasanya selalu diterima setelah bulan Maret, bahkan kadang-kadang pada bulan Juni atau Juli. Dari banyak laporan diketahui juga bahwa Dana Reboisasi (salah satu komponen dana perimbangan) sering baru diterima pada akhir tahun. Ketidaklancaran ini sering mengakibatkan ketidakpastian dalam penyediaan barang dan jasa, sehingga pada akhirnya menurunkan kualitas pelayanan pada masyarakat. 
Tabel 2: Pengaturan Dana Bagi Hasil dari Pajak dan Perubahannya

\begin{tabular}{|c|c|c|}
\hline DBH dari Pajak & $\begin{array}{l}\text { Aturan Bagi Hasil Menurut UU } \\
33 / 2004\end{array}$ & $\begin{array}{l}\text { Perubahan dibandingkan } \\
\text { dengan UU } 33 / 2004\end{array}$ \\
\hline Pajak Bumi Bangunan & $\begin{array}{l}\text { 16,2\% propinsi penghasil, } 64.8 \% \\
\text { kab/kot penghasil, } 9 \% \text { biaya pungut, } \\
6.5 \% \text { dibagi rata ke seluruh kab/kota } \\
\text { tingkat nasional, } 3.5 \% \text { insentif untuk } \\
\text { kab/kota tingkat nasional }\end{array}$ & $\begin{array}{l}\text { Tidak berubah dari UU } 25 / 1999 \\
\text { yang diuraikan lebih rinci } \\
\text { oleh PP 104/2000 (yang telah } \\
\text { diubah oleh PP 84/2001) }\end{array}$ \\
\hline $\begin{array}{l}\text { Bea Perolehan Hak Atas } \\
\text { Tanah dan Bangunan }\end{array}$ & $\begin{array}{l}\text { 16\% propinsi penghasil, } 64 \% \mathrm{kab} / \mathrm{kota} \\
\text { penghasil, } 20 \% \text { dibagi rata untuk } \\
\text { seluruh kab/kota tingkat nasional }\end{array}$ & $\begin{array}{l}\text { Tidak berubah dari UU } 25 / 1999 \\
\text { yang diuraikan lebih rinci } \\
\text { oleh PP 104/2000 (yang telah } \\
\text { diubah oleh PP 84/2001) }\end{array}$ \\
\hline $\begin{array}{l}\text { Pajak Penghasilan (PPh) } \\
\text { Pasal } 25 \text { dan Pasal } 29 \\
\text { Wajib Pajak Orang } \\
\text { Pribadi Dalam Negeri } \\
\text { dan PPh Pasal } 21\end{array}$ & $\begin{array}{l}12 \% \text { kab/kota penghasil, } 8 \% \text { propinsi } \\
\text { penghasil }\end{array}$ & $\begin{array}{l}\text { Sesuai dengan UU } 17 / 2000 \text {, } \\
\text { tidak diatur oleh UU } 25 / 1999 \text {, } \\
\text { PP } 104 / 1999 \text { dan PP } 84 / 2001\end{array}$ \\
\hline
\end{tabular}

Sumber: UU No.25/1999, PP 104/2000, UU 17/2000 dan UU 33/2004

Ketidaklancaran ini mungkin diakibatkan oleh ketidaklancaran dalam aliran dana dari pelaku eksploitasi sumberdaya alam yang membayar royalti ke pemerintah pusat dan dari pemerintah pusat ke Pemda. Di sisi lain, Pasal 23 UU 33/2004 menyatakan bahwa dana bagi hasil disalurkan berdasarkan realisasi penerimaan tahun anggaran berjalan, hal ini mengakibatkan arus kas (cash flow) keuangan daerah menjadi tidak stabil.

Dana perimbangan memiliki tiga komponen yaitu: Dana Bagi Hasil, Dana Alokasi Umum dan Dana Alokasi Khusus. Berikut adalah uraiannya.

\subsubsection{Dana Bagi Hasil (DBH)}

Secara umum, proporsi DBH antara pusat dan daerah berdasarkan UU 33/2004 tidaklah berbeda dengan apa yang tercantum dalam UU 25/1999, kecuali dalam hal bagi hasil sumberdaya alam minyak dan masuknya komponen dana reboisasi sebagai dana bagi hasil dari sumberdaya alam.

Selain itu juga terdapat beberapa klausul yang bersifat penegasan dan perubahan tentang proporsi bagi hasil. Yang dimaksud dengan penegasan di sini adalah penegasan bagi hasil pada beberapa pos anggaran penerimaan yang tidak diatur pada UU 25/1999 maupun peraturan pemerintah pelaksanaannya, tetapi diatur di dalam undang-undang sektoral, yaitu:

- UU No.17 tahun 2000 tentang Perubahan Ketiga atas UU No.7 tahun 1983 tentang pajak penghasilan

- UU No.27 tahun 2003 tentang Panas Bumi
Berikut adalah uraian kedua komponen DBH, yaitu DBH Pajak dan DBH Sumberdaya alam.

\section{DBH Pajak}

Sumber DBH Pajak terdiri dari tiga jenis pajak, yaitu: (1) Pajak Bumi Bangunan, (2) Bea Perolehan Hak Atas Tanah dan Bangunan, (3) Pajak Penghasilan.

UU 25/1999 beserta Peraturan Pemerintah turunannya PP 104/2000 yang telah diubah oleh PP 84/2001 tidak memasukkan pajak penghasilan sebagai salah satu sumber DBH Pajak. Ketentuan ini diatur pertama kali oleh UU 17/2000, kemudian UU 33/2004 menegaskan kembali pengaturan bagi hasil dari Pajak Penghasilan (PPh). Pada UU 17/2000 disebutkan bahwa daerah akan menerima $20 \%$ dari pendapatan tersebut yang dibagi menjadi $12 \%$ untuk kabupaten/kota penghasil dan $8 \%$ untuk propinsi penghasil.

\section{DBH Sumberdaya Alam}

Berdasarkan UU 33/2004, terdapat enam sektor yang menjadi sumber DBH sumberdaya alam, yaitu: (1) Kehutanan, (2) Pertambangan umum, (3) Perikanan, (4) Pertambangan minyak bumi, (5) Pertambangan gas bumi, (6) Pertambangan panas bumi.

Secara umum hampir tidak ada perubahan antara UU 33/2004 dengan UU 25/1999. Hanya saja hal rinci tentang pembagian di dalam daerah (propinsi vs kabupaten/kota) tidak diatur dalam UU 25/1999 melainkan dalam peraturan pemerintah turunannya yaitu PP 104/2000. Beberapa diantaranya ada yang baru diatur dalam PP 104/2000 (tidak ada 
dalam UU 25/1999) yaitu ketentuan tentang pembagian Dana Reboisasi (Kehutanan) dan luran Eksplorasi dan Eksploitasi (Royalty) Pertambangan Umum.

Satu-satunya perubahan hanyalah pada DBH Pertambangan Minyak dan Gas Bumi. Disini Pemda akan mendapatkan 0,5\% lebih tinggi dibanding ketentuan pada UU 25/1999. Kenaikan $0,5 \%$ tersebut digunakan untuk pelayanan pendidikan dasar dengan rincian 0,1\% untuk propinsi penghasil, 0,2\% untuk kabupaten/kota penghasil, $0,2 \%$ dibagi rata pada kabupaten/ kota di propinsi penghasil.

Selain perubahan tersebut, juga ada penambahan sumber baru bagi DBH Sumberdaya alam yaitu dari sektor Pertambangan Panas Bumi. Disini UU 33/2004 mengakomodasi ketentuan pada UU 27/2003.

Tabel 3: Pengaturan Dana Bagi Hasil dari Sumberdaya Alam dan Perubahannya

\begin{tabular}{|c|c|c|}
\hline DBH dari sumberdaya & $\begin{array}{l}\text { Ketentuan Bagi Hasil Berdasarkan UU } \\
\text { 33/2004 }\end{array}$ & $\begin{array}{l}\text { Perubahan dibandingkan dengan UU } \\
33 / 2004\end{array}$ \\
\hline \multicolumn{3}{|l|}{ Kehutanan } \\
\hline $\begin{array}{l}\text { luran Hak Pengusahaan } \\
\text { Hutan (IHPH) }\end{array}$ & $\begin{array}{l}16 \% \text { propinsi penghasil, } 64 \% \mathrm{kab} / \mathrm{kota} \\
\text { penghasil }\end{array}$ & $\begin{array}{l}\text { Tidak berubah dari UU } 25 / 1999 \\
\text { yang diuraikan lebih rinci oleh PP } \\
104 / 2000 \text { (yang telah diubah oleh PP } \\
84 / 2001 \text { ) }\end{array}$ \\
\hline $\begin{array}{l}\text { Provisi Sumberdaya } \\
\text { Hutan (PSDH) }\end{array}$ & $\begin{array}{l}16 \% \text { propinsi penghasil, } 32 \% \mathrm{kab} / \mathrm{kota} \\
\text { penghasil, } 32 \% \text { dibagi rata untuk kab/ } \\
\text { kota pada propinsi penghasil }\end{array}$ & $\begin{array}{l}\text { Tidak berubah dari UU } 25 / 1999 \\
\text { yang diuraikan lebih rinci oleh PP } \\
104 / 2000 \text { (yang telah diubah oleh PP } \\
84 / 2001 \text { ) }\end{array}$ \\
\hline Dana Reboisasi & $\begin{array}{l}40 \% \text { RHL di kab/kota penghasil, } 60 \% \\
\text { RHL nasional }\end{array}$ & $\begin{array}{l}\text { Sesuai dengan PP } 104 / 2000 \text {, tetapi } \\
\text { tidak diatur oleh UU } 25 / 1999\end{array}$ \\
\hline \multicolumn{3}{|l|}{ Pertambangan umum } \\
\hline luran tetap (Land rent) & $\begin{array}{l}16 \% \text { propinsi penghasil, } 64 \% \mathrm{kab} / \mathrm{kota} \\
\text { penghasil }\end{array}$ & $\begin{array}{l}\text { Tidak berubah dari UU } 25 / 1999 \\
\text { yang diuraikan lebih rinci oleh PP } \\
104 / 2000 \text { (yang telah diubah oleh PP } \\
84 / 2001 \text { ) }\end{array}$ \\
\hline $\begin{array}{l}\text { luran eksplorasi dan } \\
\text { eksploitasi (royalty) }\end{array}$ & $\begin{array}{l}16 \% \text { propinsi penghasil, } 32 \% \text { kab/kota } \\
\text { penghasil, } 32 \% \text { dibagi rata untuk kab/ } \\
\text { kota pada propinsi penghasil }\end{array}$ & $\begin{array}{l}\text { Sesuai dengan PP } 104 / 2000 \text {, tetapi } \\
\text { tidak diatur oleh UU } 25 / 1999\end{array}$ \\
\hline \multicolumn{3}{|l|}{ Perikanan } \\
\hline $\begin{array}{l}\text { Pungutan pengusahaan } \\
\text { perikanan }\end{array}$ & $\begin{array}{l}80 \% \text { untuk seluruh kabupaten/kota } \\
\text { nasional dengan cara dibagi rata }\end{array}$ & $\begin{array}{l}\text { Tidak berubah dari UU } 25 / 1999 \\
\text { yang diuraikan lebih rinci oleh PP } \\
104 / 2000 \text { (yang telah diubah oleh PP } \\
84 / 2001 \text { ) }\end{array}$ \\
\hline $\begin{array}{l}\text { Pungutan hasil } \\
\text { perikanan }\end{array}$ & $\begin{array}{l}80 \% \text { untuk seluruh kabupaten/kota } \\
\text { nasional dengan cara dibagi rata }\end{array}$ & $\begin{array}{l}\text { Tidak berubah dari UU } 25 / 1999 \\
\text { yang diuraikan lebih rinci oleh PP } \\
104 / 2000 \text { (yang telah diubah oleh PP } \\
84 / 2001 \text { ) }\end{array}$ \\
\hline $\begin{array}{l}\text { Pertambangan minyak } \\
\text { bumi }\end{array}$ & $\begin{array}{l}3 \% \text { propinsi penghasil, } 6 \% \mathrm{kab} / \mathrm{kota} \\
\text { penghasil, } 6 \% \text { dibagi rata ke kab/kota } \\
\text { di prop penghasil, } 0.5 \% \text { pendidikan } \\
\text { dasar }(0.1 \% \text { prop penghasil, } 0.2 \% \mathrm{kab} / \\
\text { kota penghasil, } 0.2 \% \text { dibagi rata kab/ } \\
\text { kota pada prop penghasil) }\end{array}$ & $\begin{array}{l}\text { Pembagian untuk daerah (propinsi } \\
\text { dan kabupaten/kota) naik 0,5\% } \\
\text { dibandingkan UU 25/1999. Kenaikan } \\
\text { ini baru efektif pada tahun } 2008\end{array}$ \\
\hline $\begin{array}{l}\text { Pertambangan gas } \\
\text { bumi }\end{array}$ & $\begin{array}{l}6 \% \text { propinsi penghasil, } 12 \% \mathrm{kab} / \mathrm{kota} \\
\text { penghasil, } 12 \% \text { dibagi rata ke kab/kota } \\
\text { di prop penghasil, } 0.5 \% \text { pendidikan } \\
\text { dasar }(0.1 \% \text { prop penghasil, } 0.2 \% \mathrm{kab} / \\
\text { kota penghasil, } 0.2 \% \text { dibagi rata kab/ } \\
\text { kota pada prop penghasil) }\end{array}$ & $\begin{array}{l}\text { Pembagian untuk daerah (propinsi } \\
\text { dan kabupaten/kota) naik 0,5\% } \\
\text { dibandingkan UU } 25 / 1999 . \text { Kenaikan } \\
\text { ini baru efektif pada tahun } 2008\end{array}$ \\
\hline \multicolumn{3}{|c|}{ Pertambangan panas bumi } \\
\hline $\begin{array}{l}\text { luran tetap dan luran } \\
\text { produksi }\end{array}$ & $\begin{array}{l}16 \% \text { propinsi penghasil, } 32 \% \text { kab/kota } \\
\text { penghasil, } 32 \% \text { dibagi rata untuk kab/ } \\
\text { kota pada propinsi penghasil }\end{array}$ & $\begin{array}{l}\text { Sesuai dengan UU } 27 / 2003 \text {, tidak } \\
\text { diatur oleh UU 25/1999, PP 104/1999 } \\
\text { dan PP 84/2001 }\end{array}$ \\
\hline
\end{tabular}

Sumber: UU No.25/1999, PP 104/2000, UU 27/2003 dan UU 33/2004 


\subsubsection{Dana Alokasi Umum (DAU)}

Proporsi, komponen dan rumusan perhitungan DAU mengalami perubahan. Dari sisi proporsi, terjadi kenaikan pembagian untuk daerah sebesar $1 \%$ dari 25\% menjadi 26\%. Kenaikan tersebut dilakukan secara bertahap dimulai berlakunya UU 32/2004 sampai dengan tahun 2007 kenaikan menjadi 25,5\% untuk daerah, kemudian dari tahun 2008 dan seterusnya naik menjadi $26 \%$.

Perubahan lain terjadi pada komponen DAU. UU 33/2004 membagi DAU menjadi dua komponen, yaitu: (1) Alokasi dasar; dan (2) Celah fiskal. Alokasi dasar adalah pos anggaran untuk membayar gaji pegawai negeri sipil (PNS) di daerah. Sedangkan celah fiskal adalah kebutuhan fiskal daerah setelah dikurangi oleh kapasitas fiskal daerah. Dengan demikian mungkin saja ada daerah sangat kaya yang tidak mendapatkan DAU jika daerah tersebut memiliki celah fiskal yang negatif dan nilai negatif tersebut sama dengan atau lebih besar dari alokasi dasar. Dalam keadaan ini gaji PNS dibayar oleh daerah sendiri dari PAD dan DBH. UU 25/1999 tidak memperhitungkan alokasi dasar.

Sementara rumusan perhitungan DAU mengalami perubahan. Kebutuhan fiskal (yang dulu disebut "kebutuhan wilayah") dihitung berdasarkan jumlah penduduk, luas wilayah, Pendapatan Domestik Regional Bruto (PDRB) per kapita, indeks kemahalan konstruksi dan indeks pembangunan manusia 4 . Sedangkan pengeluaran rata-rata, indeks kenaikan harga dan indeks kemiskinan relatif tidak lagi mempengaruhi perhitungan seperti pada UU 25/1999. Kapasitas fiskal (yang dulu disebut "potensi ekonomi“) hanya memperhitungkan PAD dan DBH, sedangkan pajak bumi bangunan, pajak penghasilan dan bea perolehan hak atas tanah dan bangunan tidak lagi mempengaruhi perhitungan seperti pada UU 25/1999.

\section{Dana Alokasi Khusus (DAK)}

Dalam UU 25, DAK yang disebut secara spesifik adalah DAK Dana Reboisasi (DAK-DR). Oleh karena itu, Pemerintah Daerah biasanya membagi DAK menjadi DAK-DR dan DAK-Bukan DR. Pada UU 33/2004, Dana Reboisasi tidak lagi masuk dalam komponen DAK tetapi masuk dalam komponen Dana Bagi Hasil yang ditujukan untuk kegiatan Rehabilitasi Hutan dan Lahan (RHL). Pembagiannya tidak mengalami perubahan yaitu $40 \%$ untuk kegiatan RHL di kabupaten/kota penghasil dan sisanya $60 \%$ digunakan untuk kegiatan RHL tingkat nasional (Lihat Tabel 3).

UU 33/2004 mempertegas lagi ketentuan dana pendamping seperti telah diatur oleh PP 104/2000 yaitu bahwa daerah wajib menyediakan dana pendamping sekurang-kurangnya $10 \%$ yang berasal dari APBD.

\subsection{Lain-Lain Pendapatan}

Dalam UU 25/1999 "lain-lain pendapatan" disebut dengan "lain-lain penerimaan yang sah". Baik UU 25/1999 maupun PP 104/2000 tidak merinci lebih jauh tentang komponen ini. Namun jika kita memperhatikan pelaksanaannya yaitu dengan mengacu pada kasus di Kabupaten Kutai Bara lewat laporan keuangan Pemkab Kutai Barat tahun 2002, terlihat ada tiga komponen yang menjadi bagian lain-lain penerimaan yang sah, yaitu:

1. Penerimaan dari subsidi propinsi

2. Penerimaan kabupaten lainnya

3. Penerimaan lain-lain.

Penerimaan dari subsidi propinsi dibagi menjadi lima pos anggaran, yaitu:

1. Subsidi pembangunan

2. Bagi hasil pajak bahan bakar kendaraan bermotor (PBBKB)

3. Bagi hasil pajak kendaraan bermotor (PKB)

4. Bagi hasil bea balik nama kendaraan bermotor

5. Bagi hasil pajak pemanfaatan air bawah tanah dan air permukaan

Sistem bagi hasil pajak propinsi diatur oleh UU 34/2000 seperti dapat dilihat pada tabel 4. Dengan asumsi bahwa UU 34/2000 tidak diganti maka komponen bagi hasil pajak propinsi masuk di dalam penerimaan daerah kabupaten/kota.

UU 34/2004 tidak mengatur pembagian pajak propinsi, hal ini mungkin karena UU 34/2004 hanya mengatur mengenai perimbangan keuangan antara pemerintah pusat dan Pemda. Namun anehnya dalam UU 34/2004 dikatakan

Rumus Perhitungan DAU untuk suatu kabupaten adalah sebagai berikut:

$$
D A U=\text { Alokasi Dasar }+\left[\frac{\text { Kebutuhan }- \text { Kapasitas }}{\text { Total celah fiskal seluruh kab/kota }} \times \sum D A U \text { seluruh kab/kota }\right]
$$


Tabel 4: Tarif dan Pembagian Pajak Propinsi

\begin{tabular}{lll}
\hline Bagi hasil pajak pajak propinsi & Tarif maksimal & $\begin{array}{l}\text { Pembagian ke Kabupaten/Kota } \\
\text { di Propinsi yang bersangkutan }\end{array}$ \\
\hline Penghasilan lain & & \\
\hline Bagi hasil pajak pajak propinsi & $5 \%$ & paling sedikit 70\% \\
\hline $\begin{array}{l}\text { Bagi hasil pajak bahan bakar } \\
\text { kendaraan bermotor, PBBKB }\end{array}$ & $5 \%$ & paling sedikit 30\% \\
\hline $\begin{array}{l}\text { Bagi hasil pajak kendaraan bermotor } \\
\text { (PKB) }\end{array}$ & $10 \%$ & paling sedikit 30\% \\
\hline $\begin{array}{l}\text { Bagi hasil bea balik nama kendaraan } \\
\text { bermotor }\end{array}$ & $20 \%$ & paling sedikit $70 \%$ \\
\hline $\begin{array}{l}\text { Bagi hasil pajak pemanfaatan air } \\
\text { bawah tanah dan air permukaan }\end{array}$ & & \\
\hline
\end{tabular}

Sumber: UU No.34 tahun 2000

bahwa "lain-lain pendapatan" hanya terdiri dari dua sumber yaitu dana hibah dan dana darurat ${ }^{5}$.

\section{Pembiayaan}

Dalam Pasal 1 UU 33/2004 dijelaskan definisi "pembiayaan" yaitu:

"Pembiayaan adalah setiap penerimaan yang perlu dibayar kembali dan/atau pengeluaran yang akan diterima kembali, baik pada tahun anggaran yang bersangkutan maupun tahuntahun anggaran berikutnya".

Dengan adanya pemisahan antara pendapatan dan pembiayaan, maka beberapa pos anggaran penerimaan masuk sebagai bagian dari komponen pembiayaan, yaitu:

1) Sisa lebih perhitungan anggaran daerah

2) Pinjaman daerah

3) Dana cadangan daerah

4) Hasil penjualan kekayaan daerah yang dipisahkan.

Khusus tentang pinjaman daerah, UU $33 / 2004$ lebih memiliki rambu-rambu terutama tentang batasan jumlah pinjaman daerah. Di sini dikatakan bahwa batas maksimal kumulatif pinjaman tidak boleh melebihi 60\% dari Produk Domestik Bruto tahun bersangkutan. UU 33/2004 juga memperinci sumber-sumber pinjaman daerah, yaitu:

1) Pemerintah

2) Pemerintah daerah lain

3) Lembaga keuangan bank

4) Lembaga keuangan bukan bank

5) Masyarakat lewat obligasi daerah. Obligasi daerah diterbitkan melalui pasar modal, dan tidak dijamin oleh pemerintah pusat
Hal yang membedakan UU 32/2004 dengan UU 25/1999 adalah bahwa berdasarkan UU 33/2004 tidak diperkenankan melakukan pinjam langsung ke luar negeri. Pinjaman dari luar negeri akan diberikan melalui pemerintah pusat.

\section{Pengelolaan Keuangan Daerah}

\subsection{Surplus Defisit Anggaran}

Tidak seperti UU 25/1999 yang tidak memperbolehkan adanya defisit anggaran, UU 32/2004 dan UU 33/2004 mengatur beberapa hal apabila APBD diasumsikan surplus atau defisit. Defisit diperbolehkan sepanjang tidak melebihi 3\% dari total PDRB tahun bersangkutan. Kebijakan yang memperbolehkan defisit anggaran seperti dua sisi mata pedang. Di satu sisi dapat meningkatkan laju pembangunan karena pemda dapat membuat anggaran belanja lebih besar dibandingkan pendapatan pada tahun berjalan. Pemda juga dituntut untuk dapat berkreasi dalam mencari sumber-sumber pembiayaan untuk menutupi defisit. Tapi di sisi lain jika tidak ada pengendalian yang baik maka hal ini dapat memicu terjadinya krisis keuangan daerah secara berkepanjangan.

\subsection{Pungutan Memberatkan Kegiatan Perekonomian}

Seperti kita ketahui ada banyak laporan yang menyebutkan adanya pungutan-pungutan pemda yang memberatkan kegiatan ekonomi. Pungutan-pungutan tersebut seringkali tidak memiliki dasar hukum yang jelas. Oleh karena itu Pasal 158 UU 32/2004 secara tegas menjelaskan bahwa pemerintahan daerah dilarang melakukan pungutan atau dengan sebutan lain, diluar yang telah ditetapkan undang-undang. 


\subsection{Prioritas Dan Struktur Belanja Daerah}

Prioritas belanja daerah adalah hal penting yang menentukan arah kebijakan anggaran daerah. Untuk mengantisipasi agar belanja daerah tidak keluar dari rel "kewajiban daerah" maka Pasal 167 UU 32/2004 mempertegas prioritas belanja daerah. Disini dikatakan bahwa belanja daerah diprioritaskan untuk melindungi dan meningkatkan kualitas kehidupan masyarakat yang diwujudkan dalam bentuk peningkatan pelayanan dasar, pendidikan, penyediaan fasilitas kesehatan, fasilitas sosial dan fasilitas umum yang layak, serta mengembangkan sistem jaminan sosial.

Selain penetapan prioritas belanja, Pasal 167 UU 32/2004 juga mempertegas beberapa hal yang harus dipertimbangkan dalam pelaksanaan belanja daerah, yaitu:

- analisis standar belanja

- standar harga

- tolok ukur kinerja

- standar pelayanan minimal.

UU 33/2004 juga mengharuskan anggaran belanja sesuai dengan sistem anggaran berbasis kinerja (performance based budget). Struktur anggaran belanja tidak lagi dibagi dalam dua komponen besar yaitu belanja rutin dan belanja pembangunan, tetapi dibagi berdasarkan organisasi, fungsi, program, kegiatan dan jenis belanja. Dengan demikian, setiap belanja yang dilakukan harus memiliki alasan dan latar belakang serta kerangka logis yang jelas sesuai dengan perencanaan daerah serta fungsi-fungsi dan program-program pemerintahan daerah. Bahkan setiap lembar rencana belanja harus disertai dengan indikator-indikator kinerja yang jelas.

\subsection{Perencanaan dan Penetapan APBD}

Berbeda dengan UU 25/1999 yang tidak mengatur mengenai perencanaan anggaran, UU 33/2004 memiliki beberapa klausul yang mengatur proses perencanaan anggaran. Pesan utama yang dapat ditangkap dari UU 33/2004 adalah bahwa perencanaan anggaran harus sejalan dengan perencanaan pembangunan. $\mathrm{Hal}$ ini penting karena di beberapa daerah seringkali perencanaan anggaran dan perencanaan pembangunan berada pada jalur proses yang berbeda 6 .

Penetapan APBD menurut UU 22/1999 dan PP No.105/2000) hanya melibatkan kepala daerah dan DPRD, namun dalam UU 32/2004 melibatkan Gubernur bagi APBD Kabupaten/
Kota, sementara bagi APBD Propinsi harus melalui evaluasi oleh Menteri Dalam Negeri (Mendagri). Bahkan Gubernur dan Mendagri berhak untuk mem'veto' jika RAPBD Kabupaten/Kota yang telah disepakati bersama oleh kepala daerah dan DPRD dinilai tidak sesuai dengan ketentuan. Menurut penjelasan UU 32/2004, tujuan evaluasi tersebut adalah untuk tercapainya keserasian antara kebijakan daerah dan kebijakan nasional, keserasian antara kepentingan publik dan kepentingan aparatur, serta untuk meneliti sejauh mana APBD tidak bertentangan dengan kepentingan umum, peraturan yang lebih tinggi, dan peraturan daerah lainnya.

\subsection{Pelaporan dan Pertanggungjawaban}

Berbeda dengan UU 22/1999 dan PP 105/2000 yang menetapkan bahwa proses pelaporan dan pertanggungjawaban hanya melibatkan DPRD, UU 32/2004 menetapkan adanya kewajiban pemeriksaan (audit) oleh Badan Pemeriksa Keuangan (BPK). Audit keuangan dilakukan sebelum kepala daerah menyerahkan rancangan peraturan daerah tentang pertanggungjawaban APBD kepada DPRD. UU 32/2004 memberikan batas waktu enam bulan setelah tahun anggaran berakhir untuk menyelesaikan laporan keuangan dan pemeriksaan oleh BPK.

Ketentuan ini mungkin dibuat untuk mengantisipasi adanya fungsi check and balances DPRD yang tidak berjalan efektif. Seperti diketahui banyak laporan yang menunjukkan terjadinya kolusi antara kepala daerah dan DPRD dalam menyelewengkan dana APBD.

Selain itu UU 32/2004 juga mengharuskan laporan keuangan pelaksanaan APBD dilengkapi dengan laporan keuangan Badan Usaha Milik Daerah (BUMD) selain laporan realisasi APBD, neraca, dan laporan arus kas.

UU 25/1999 dan UU 33/2004 sama-sama mengatur penyelenggaraan Sistem Informasi Keuangan Daerah atau yang lebih populer sebagai SIMKUDA. Kedua UU tersebut juga menyatakan bahwa informasi-informasi di dalam SIMKUDA bersifat terbuka yang dapat diketahui, diakses dan diperoleh oleh masyarakat. Perbedaannya adalah pada UU 33/2004 disebutkan secara rinci jenis-jenis informasi yang harus ada dalam SIMKUDA, yaitu:

1. APBD dan laporan realisasi APBD provinsi, kabupaten, dan kota;

2. Neraca Daerah;

3. Laporan Arus Kas;

4. Catatan atas Laporan Keuangan Daerah;

5. Dana Dekonsentrasi dan Dana Tugas Pembantuan; 
6. Laporan Keuangan Perusahaan Daerah (BUMD); dan

7. Data yang berkaitan dengan kebutuhan fiskal dan kapasitas fiskal daerah.

Perkembangan sampai dengan saat ini memperlihatkan belum banyak pemerintahan daerah yang sudah menjalankan ketentuan tentang pelaporan, pertanggungjawaban dan transparansi keuangan daerah. Jika ketentuan ini benar-benar dilaksanakan dan kebijakan mengenai transparansi lewat SIMKUDA dijalankan dengan baik maka fungsi pengawasan masyarakat dapat berjalan efektif.

\section{Kesimpulan}

Perubahan peraturan perundangan keuangan daerah memberikan peluang terjadinya peningkatan pendapatan daerah lewat kenaikan proporsi bagi hasil pada DBH tambang minyak dan gas bumi dan DAU serta penambahan beberapa sumber-sumber baru seperti pajak penghasilan dan DBH pertambangan panas bumi

UU 32/2004 dan UU 33/2004 lebih menekankan pemerintahan daerah untuk menjamin pelayanan dasar warga negara, hal ini berarti lebih mendukung upaya penanggulangan kemiskinan. Bahkan pelayanan pendidikan dasar mendapatkan perhatian khusus lewat peningkatan $0,5 \%$ DBH pertambangan minyak dan gas bumi.

UU 32/2004 dan UU 33/2004 lebih menjamin adanya perbaikan pengelolaan keuangan daerah terutama dari sisi transparansi, akuntabilitas, kesesuaian dengan perencanaan pembangunan dan pencegahan pungutan liar yang membebani kegiatan ekonomi.

\section{Catatan kaki}

1 Konsultan Peneliti pada Program Kemiskinan dan Desentralisasi CIFOR/BMZ (cahyat@cbn. net.id). Ucapan terimakasih disampaikan pada Ahmad Dermawan di CIFOR yang telah mengulas dan berkomentar atas versi rancangan.

2 Tambang galian $\mathrm{C}$ adalah bahan tambang yang tidak termasuk dalam golong strategis (golongan A) dan vital (golongan B), misalnya: pasir kwarsa, batu permata, batu apung, batu apung, granint, garam batu, dll.

3 Padahal PAD sangat strategis karena merupakan sumber pendapatan yang dapat langsung dipungut dan disimpan tanpa harus menyetorkannya terlebih dahulu ke Pemerintah Pusat. PAD akan sangat membantu mengatasi masalah arus kas (cash flow) yang biasa terjadi pada awal sampai dengan pertengahan tahun. Sedangkan bagi kepala daerah dan DPRD, PAD penting karena menentukan jumlah dana penunjang operasional kepala daerah dan DPRD.

${ }^{4}$ Indeks Pembangunan Manusia (Human Development Index) untuk Indonesia dibuat bersama oleh UNDP, BPS dan Bappenas. Dalam HDI juga ada Human Poverty Index (HPI) sebagai salah satu bagiannya.

${ }^{5}$ Dana Darurat adalah dana yang berasal dari APBN yang dialokasikan kepada Daerah yang mengalami bencana nasional, peristiwa luar biasa, dan/atau krisis solvabilitas

6 Bahkan di salah satu daerah ditemukan hasil perencanaan pembangunan dari proses musyawarah pembangunan (Musrenbang) sama sekali tidak dijadikan acuan dalam perencanaan anggaran.

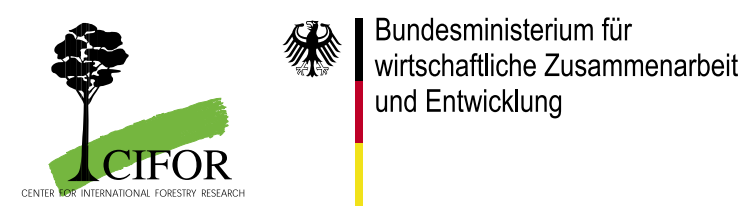

Center for International Forestry Research, CIFOR Alamat kantor: Jalan CIFOR, Situ Gede, Sindang Barang Bogor Barat 16680, Indonesia.

Alamat surat: P.O. Box. 6596 JKPWB, Jakarta 10065 Indonesia
Tel: +62(251) 622622 Fax: +62(251) 622100

E-mail: cifor@cgiar.org

Website: www.cifor.cgiar.org

Foto sampul oleh: Eva Wollenberg 